\title{
Скелетні м'язи як ендокринний регулятор розвитку метаболічного синдрому
}

\author{
УДК 796;797;798;799;796.015.62 \\ С. Б. Дроздовська, О. О. Гуренко, Ю. М. Порадун
}

Національний університет фізичного виховання і спорту України, Київ, Україна

Резюме. Метаболічний синдром - поєднання порушень обміну речовин, що виникають на тлі ожиріння, інсулінорезистентності, артеріальної гіпертензії, дисліпідемії та супроводжуються порушенням ліпідного, пуринового та вуглеводного обміну. Огляд присвячений міокіну IL-6, його регуляції за допомогою фізичних вправ та ролі у формуванні метаболічного синдрому. Мета. Проаналізувати роль скелетних м'язів як ендокринного фактора регуляції метаболічного синдрому. Методи. Системний та порівняльний аналіз, аналіз наукової літератури, контентаналіз і метод систематизації отриманої інформації. Було опрацьовано відомості наукової літератури в таких базах даних: Web of Science, Scopus, PubMed, Google, Scholar, Medline. Результати. В роботі детально вивчено та проаналізовано роль цитокіну рецептора gр130 інтерлейкіну-6 (IL-6), що тісно пов'язаний з хронічними запальними станами як основними компонентами метаболічного синдрому. При гіподинамії відзначається високий вміст IL-6 у плазмі, в той час як постійні тренування знижують цей показник, збільшуючи лише рівень внутрішньом'язової фракції цитокіну. Таким чином, гіподинамія призводить до розвитку інсулінорезистентності та визначає IL-6 гормоном, що опосередковує перехресну взаємодію між чутливими до інсуліну тканинами й острівцями підшлункової залози через GLP-1 та впливає на зниження середніх значень TNF- $\alpha$, IL-2, IL-4, IL-6, CRP у сироватці через збільшення внутрішньом'язової концентрації під час виконання фізичних навантажень.

Незважаючи на численні публікації та інтерес до вказаної проблематики, на сьогодні чітко не визначені основні рекомендації щодо спрямованості та інтенсивності фізичної активності для пацієнтів з метаболічним синдромом.

Даний огляд присвячений міокіну IL-6, його регуляції за допомогою фізичних вправ та сигнальним шляхам у скелетних м'язах, а також ролі у формуванні метаболічного синдрому.

Ключові слова: метаболічний синдром, міокіни, інтерлейкін-6, інсулінорезистентність, рухова активність.

\section{Skeletal muscles as an endocrine regulator of metabolic syndrome development}

\section{S. B. Drozdovska, O. O. Hurenko, Yu. M. Poradun}

National University of Physical Education and Sport of Ukraine, Kyiv, Ukraine

Abstract. Metabolic syndrome is a combination of metabolic disorders that occur against the background of obesity, insulin resistance, hypertension, dyslipidemia and are accompanied by disorders of lipid, purine and carbohydrate metabolism. Objective. Analyze the role of skeletal muscle as an endocrine factor in metabolic syndrome regulation. Methods. System and comparative analysis, analysis of scientific literature, content analysis and method of the received information systematization. Results. The data described in the review of numerous meta-analyzes and the results of studies involving people with metabolic syndrome, indicate that active skeletal muscle activity inhibits the progression of metabolic disorders, therefore, people with metabolic syndrome are recommended a combined therapeutic regimen that includes regular physical activity. activity. The role of the cytokine gp130 receptor interleukin-6 (IL-6), which is closely related to chronic inflammatory conditions as the main components of the metabolic syndrome, was studied and 
analyzed in detail. Hypodynamia has a high content of IL-6 in plasma, while regular exercise reduces this figure, increasing only the level of intramuscular fraction of the cytokine, so hypodynamics leads to the development of insulin resistance and determines IL- 6 hormone, which mediates cross-interaction to insulin by fabrics and islands of a pancreas through GLP-1 and influences decrease in average values of TNF $\alpha$, IL-2, IL-4, IL-6, CRP in serum because of increase in intramuscular concentration during performance of physical activities.

Despite numerous publications and interest in this issue, to date, the basic recommendations for the direction and intensity of physical activity for patients with metabolic syndrome are not clearly defined.

This review focuses on the myokine IL-6, its regulation through exercise and signaling pathways in skeletal muscle, as well as its role in the formation of metabolic syndrome.

Keywords: metabolic syndrome, myokines, interleukin-6, insulin resistance, physical activity.

Постановка проблеми. Метаболічний синдром (МС) - мультифакторний клінічний стан, обумовлений комплексом генетичних, нейрогуморальних фракторів та особливостями способу життя людини [1]. Це патологічний стан, що охоплює всі органи і системи в організмі та представляє собою поєднання кількох фракторів, таких як гіперінсулінемія, артеріальна гіпертензія, дисліпідемія та ожиріння. Поєднання таких патологічних процесів збільшує ризик серцево-судинних та цереброваскулярних захворювань [2].

Літературні дані показують, що в осіб з діагностованим МС відзначається істотне зниження якості життя внаслідок коморбідності, а також зменшення очікуваної тривалості життя в середньому на 5-7 років. Слід відзначити, що на тлі МС зростає ризик розвитку серцево-судинних, легеневих, ниркових та онкологічних захворювань, які суттєво впливають на частоту летальних випадків [3, 4].

Причиною збільшення частоти ожиріння за останні десятиліття фрахівці вважають, перш за все, соціальні умови життя. Факторами, що сприяють ожирінню, $\epsilon$ недостатність знань про здорове харчування і недостатня рухова активність. Однак найбільш чутливі до такого впливу особи мають спадкову схильність [5].

Поєднання метаболічних порушень (ожиріння, порушена толерантність до глюкози, гіперінсулінемія, цукровий діабет, дисліпопротеїнемія тощо) і серцево-судинних захворювань (артеріальна гіпертензія, атеросклероз, ішемічна хвороба серця) неодноразово було описано в літературі під різними назвами - «поліметаболічний синдром», «метаболічний трисиндром», «синдром достатку» та ін. [6]. У 1988 р. G. H. Reaven вперше поєднав порушення вуглеводного обміну та запропонував термін «метаболічний синдром», або «синдром X», що об'єднав тканинну інсулінорезистентність з компенсаторною базальною гіперінсулінемією, гіперліпідемію (гіпертригліцеридемію і гіпоальфахолестеринемію), артеріальну гіпертензію та порушення толерантності до глюкози. Величезний вплив, який метаболічні порушення чинять на системи гемореології, гемостазу та ендотелію, призводить до розвитку і прогресування серцево-судинних захворювань, зокрема до виникнення ішемічного інсульту [7].

Причина, через яку дані критерії вчені описують як синдром, а не як окремі і незалежні фрактори ризику, полягає в тому, що вони керуються загальним патофрізіологічним механізмом. Клінічне значення цього синдрому найкраще встановлено у дорослих.

Серед фракторів ризику, що модифікуються та асоційовані 3 високою кардіоваскулярною смертністю населення України та країн Європи, слід відзначити підвищений артеріальний тиск (АТ) - артеріальну гіпертензію (АГ); куріння; дисліпідемію (ДЛП), гіперглікемію; низьку фізичну активність; надлишкову масу тіла та абдомінальне ожиріння (AO), порушення в харчуванні або аліментарний фактор. МС включає такі головні компоненти - AO, порушення толерантності до глюкози (ПТГ), або цукровий діабет ІІ типу (ЦД 2), ДЛП та гіпертонічну хворобу (ГХ). Провідними патогенетичними механізмами МС вважають гіперінсулінемію (ГІ), інсулінорезистентність (IP), дисбаланс у системі гормонів жирової тканини - адипокінів, активацію симпатоадреналової та ренін-ангіотензинової систем, диссункцію ендотелію, гіперпродукцію ростових чинників, прозапальних цитокінів і проангіогенних фракторів, гіперурикемію [1].

На сьогодні питання корекції метаболічного синдрому $€$ достатньо актуальним та потребує залучення до протоколів лікування нових методів впливу на його маніфестацію і прогресування та превенції розвитку супутніх ускладнень. Наукова спільнота активно залучена у процес дослідження міокінів як ключового регулятора гомеостазу глюкози та опосередкованої корекції його рівнів через роботу скелетних м'язів під час фрізичних навантажень, але наразі в науковій літературі не виділено чіткі рекомендації щодо спрямованості 
фрізичної активності для пацієнтів з МС та супутніми патологічними станами.

Ця робота $€$ фрагментом планової наукової роботи Національного університету фрізичного виховання і спорту України «Вплив екзогенних та ендогенних фракторів на перебіг адаптаційних реакцій організму до фрізичних навантажень різної інтенсивності» (номер держреєстрації 012U108187).

Мета дослідження - проаналізувати роль скелетних м'язів як ендокринного фрактора регуляції МС.

Методи дослідження: системний та порівняльний аналіз, аналіз наукової літератури, контент-аналіз і метод систематизації отриманої інформації. ня

Результати дослідження та їх обговорен-

Критерії визначення метаболічного синдрому. До діагностичних критеріїв МС, сорормульованих експертами ВООЗ (1999) [8], належать цукровий діабет, порушення толерантності до глюкози, гіперглікемія натще або інсулінорезистентність у поєднанні з двома критеріями, які представлено в таблиці 1.

У 2005 р. Міжнародна фредерація діабету (IDF) запропонувала діагностичні критерії, в основі яких лежать антропометричні, патофрізіологічні i лабораторні показники [9].

Критерії MC (IDF, 2005):

1. Окружність талії (ОТ) > 94 см у чоловіків, $>80$ см у жінок.

2. Глюкоза в капілярній крові натще $>$ 6,1 ммоль/л, або ПТГ (75 г глюкози).

3. АТ $>130 / 85$ мм рт. ст.

4. Тригліцериди (ТГ) > 1,7 ммоль/л.

5. Ліпопротеїни високої щільності (ЛПВЩ) $<0,9$ ммоль/л у чоловіків, < 1,0 ммоль/л у жінок.

Діагноз вважається вірогідним за наявності не менше трьох показників, що збігаються. Однак через наявність ряду недоліків критерії діагностики МС (1999) не отримали широкого застосування й експерти Національної освітньої програми США - NCEP Adult Treatment Panel (ATP) III (2001) [10] - запропонували більш прийнятні критерії для виконання широкомасштабних епідеміологічних досліджень, а саме:

- абдомінальне ожиріння (за ОТ) > $102 \mathrm{~cm}$ для чоловіків, > 88 см для жінок;

- ТГ > 150 мг/дл (1,69 ммоль/л);

- ХС ЛПВЩ < $40 \mathrm{мг/дл} \mathrm{для} \mathrm{чолові-}$ ків $(1,29$ ммоль/л), < 50 мг/дл для жінок (1,04 ммоль/л);

- AT >130/85 мм рт. ст.;
ТАБЛИЦЯ 1 - Критерії діагностики метаболічного синдрому ВООЗ (1999) [8]

\begin{tabular}{|l|l|}
\hline ОТ/ОС & $>0,90$ (чоловіки), > 0,85 (жінки) \\
\hline $\begin{array}{l}\text { ТГ } \\
\text { або ХС лПВЩ }\end{array}$ & $\begin{array}{l}>1,7 \text { ммоль/л } \\
<0,9 \text { ммоль/л (чоловіки) і } \\
<1,0 \text { ммоль/л (жінки) }\end{array}$ \\
\hline АТ & $>140 / 90$ рт. ст. \\
\hline $\begin{array}{l}\text { Альбумінурія } \\
\text { або співвідношення альбу- } \\
\text { мін/креатинін }\end{array}$ & $>20$ мкг/хв \\
\hline
\end{tabular}

- глюкоза натще > 110 мг/дл (6,1 ммоль/л).

Робота 3 уніфікації критеріїв МС активно ведеться провідними організаціями світу: A Joint Interim Statement of the International Diabetes Federation Task Force on Epidemiology and Prevention; National Heart, Lung, and Blood Institute; American Heart Association; World Heart Federation; International Atherosclerosis Society; and International Association for the Study of Obesity [11].

Таким чином, до теперішнього часу єдині діагностичні критерії МС чітко не визначено, $\epsilon$ суперечності внаслідок реальної оцінки частоти виникнення МС у населення конкретного регіону через використання як різних діагностичних критеріїв, так і індивідуальних коливань окружності талії залежно від етнічної приналежності населення, особливостей віку та гендерної приналежності.

Деякими авторами доведено, що показник відношення окружності талії до окружності стегон (ОT/OC) представляє кращу залежність ожиріння та розвитку серцево-судинних ускладнень, ніж IMT. При надмірній масі тіла зростання відносного ризику ішемічної хвороби серця (IXC) статистично незначуще, але при прогресуванні ожиріння ризик збільшується в 1,5-2 рази. Частота порушень мозкового кровообігу також залежить від ступеня ожиріння. Поєднання ожиріння з АГ підвищує ризик виникнення IXC у 2-3 рази, інсульту - в 7 разів [12].

Виділяють такі варіанти МС: повний (поєднання АГ, ДЛП, ожиріння, інсулінонезалежного цукрового діабету (ІНЦД) і неповний (не включає одну з перерахованих складових). Ряд дослідників пропонують говорити про наявність МС при виявленні будь-яких двох нижчеперелічених критеріїв: абдомінально-вісцерального ожиріння, IP, ГІ, ДЛП (ліпідної тріади), АГ, ЦД 2, раннього атеросклерозу / IXC, порушення гемостазу, гіперурикемії і подагри, мікроальбумінурії, гіперандрогенії. За відсутності порушень вуглеводного обміну рекомендується встановити фракт IP [13].

Патогенез метаболічного синдрому. Об'єднуючою основою усіх симптомів ускладнення МС 
$€$ IP та супутня ГІ. Резистентність периферичних тканин - м'язової, жирової, клітин печінки викликає компенсаторну реакцію - збільшення секреції інсуліну та ГІ. ГІ, з одного боку, є компенсаторною, тобто необхідною для подолання IP та підтримання нормального транспорту глюкози в клітину; з іншого боку - патологічною, що сприяє розвитку метаболічних, гемодинамічних та органічних порушень з розвитком ЦД 2, IXC та ін. B умовах ГІ та зниження чутливості гепатоцитів знижується засвоєння інсуліну печінкою та збільшується продукція вільних жирних кислот (ЖК) у портальній системі печінки. ЖК пригнічують гальмівну дію інсуліну на глюконеогенез, таким чином сприяючи збільшенню продукції глюкози печінкою, що призводить до більш вираженої ГІ та IP [14]. IP та ГІ, як правило, супроводжують порушення ліпідного обміну з розвитком атерогенної ДЛП. Атерогенна ДЛП характеризується гіпертригліцеридемією, підвищеним рівнем ліпопротеїнів низької щільності (ХС ЛПНЩ), зниженням концентрації ліпопротеїнів високої щільності (ХС ЛПВЩ), підвищенням рівня аполіпопротеїну $\mathrm{B}$, а також високим рівнем неетерифрікованих ЖК плазми і вираженим підйомом рівня ліпопротеїнів, багатих ТГ [13]. За даними інших дослідників, поєднання окремих компонентів може розглядатися в рамках МС тільки за наявності обов'язкового встановлення фракту IP. Слід зазначити, що наявність або відсутність будь-яких проявів МС багато в чому залежить від індивідуальних компенсаторних механізмів, причому у різних хворих резерви компенсації різних проявів МС можуть бути виражені по-різному.

Епідеміологія метаболічного синдрому. У загальній популяції висока поширеність МС коливається в межах 14-24\% і збільшується з віком. Так, серед осіб 20-29 років МС можна діагностувати у 6,7 \% жителів; 60-69 років - у 43,5\%, 70 років і старше - у $42 \%$ [13]. За останніми оцінками В003, на сьогоднішній день надлишкова маса тіла зареєстрована у 1,7 млрд осіб, це приблизно у 30 \% жителів планети. Ожиріння діагностоване у 10-25 \% європейського населення і майже однієї третини жителів США.

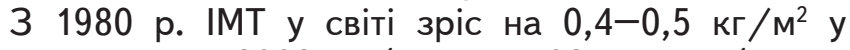
дорослих. У 2008 р. близько 502 млн осіб мали IMT > 30 кг/M² [15]. За оцінками вчених, на МC страждають більше $20 \%$ дорослого населення світу. Вважається, що АО є переважаючим фактором ризику МС. Згідно з прогнозами, до 2030 р. $50 \%$ дорослих будуть класифіковані з виявленим ожирінням, водночас МС стане серйозною проблемою для служб охорони здоров'я [16].
Ендокринна роль скелетних м'язів. Гіподинамію давно зарахували до списку факторів ризику атеросклерозу, ожиріння і деяких інших захворювань. За останні десятиліття було зроблено безліч спроб кількісно оцінити профрілактичну і лікувальну дію фрізичних вправ.

Наймасштабніше спостереження включало в себе близько 900000 учасників, які перебували під наглядом не менше 20 років. Дослідження показали зниження ризику смертності з різних причин на $33 \%$, а ризику розвитку серцево-судинної патології в осіб, які практикують регулярні помірні фрізичні навантаження (ФН), - на $35 \%$ [17]. Разом з тим відомо, що різні фрізичні фрактори можуть здійснювати реальний модифікуючий вплив на процеси гормональної регуляції ліпідного та вуглеводного обміну, що передбачає перспективність наукових досліджень щодо їх застосування в лікуванні та профрілактиці МС. Встановлено, що ФН за рахунок активації метаболічних процесів сприяють зменшенню маси тіла, дозволяють задіяти в активізації енергетичного обміну ТГ, трансорормуючи їх у вільні ЖК і тим самим сприяючи зменшенню жирових запасів.

Протективний ефект ФН щодо хронічних хвороб пояснюється протизапальним ефектом регулярних ФН. ФН надають захисний ефект завдяки впливу на енергетичний баланс, через механізми активації ліполізу, утилізації глюкози і ЖК. Новий етап у розумінні наукою патогенної дії гіподинамії і саногенності фрізичної активності відкриває концепцію ендокринних фрункцій м'язової тканини.

В осіб з малорухливим способом життя відзначається зниження процесів засвоєння ТГ і глюкози, що в кінцевому підсумку призводить до розвитку інсулінорезистентності та характеризується хронічним системним запаленням [18, 19]. Хронічне системне запалення призводить до інсулінорезистентності, ДЛП, ендотеліальної дисорункції, розвитку атеросклерозу, нейродегенерації, анемії і втрати м'язової маси, що може сприяти інвалідизації і зниженню фрізичної активності. Нестача фрізичної активності провокує накопичення вісцерального жиру, тим самим посилює запалення, спричиняючи виникнення метаболічних порушень і розвитку ряду хронічних захворювань [20].

Згідно з дослідженнями S. Motamed et al. (2019), серед 3800 чоловіків і жінок 35-65 років МС було виявлено у 1699 осіб (521 чоловік і 1178 жінок, середній вік 48,8 \pm 7,8 року), рівень фрізичної активності респондентів був значно знижений [18]. 
За даними J. Xiao et al. (2016), при вивченні зв'язку фрізичної активності і малорухливого способу життя з розвитком МС у 20502 жителів (13 505 жінок і 6997 чоловіків) сільських районів Китаю МС було виявлено у 21,6 \% респондентів. У чоловіків частота виявлення МС була значно нижче, ніж у жінок. Низькі ризики МС спостерігалися у тих, хто мав більш високу фрізичну активність. Найвищий рівень інтенсивної фрізичної активності сприяв значному зниженню ризику розвитку MC на $15-40 \%$, за винятком низького рівня ЛПВЩ у чоловіків. У жінок, які займалися фрізичною активністю, шанси розвитку центрального ожиріння, гіперглікемії і гіперхолестеринемії були знижені на 15-30 \% [21, 22]. Разом з тим безперервний сон тривалістю більше 8 год на день був пов'язаний з ризиком розвитку IP і гіперліпідемії. Встановлено, що фрізична активність має значний профрілактичний ефект у попередженні розвитку МС і окремих його компонентів [21].

Скелетні м'язи, так само як кардіоміоцити і жирова тканина, $\epsilon$ ендокринним органом та виробляють біорегулятори, які діють не тільки паракринно і юкстакринно, але й ендокринно, дистантно - через кровотік [23]. Скорочуючись, скелетні м'язи виділяють ряд аутакоїдів - сигнальних органічних молекул короткої дистантної дії. Серед них цитокіни (та інші пептиди), названі міокінами, які протидіють прозапальним аутакоїдам жирової тканини - адіпокінам. Міокіни взаємодіють з клітинами в аутокринній та паракринній манері в межах м'язів, а при інтенсивній продукції - за ендокринним механізмом - через лімфу та кров [24].

Серед існуючих міокінів виділяють: іризин, декорин, остеонектин, інтерлейкін-15 (IL-15), мозковий нейротрофічний фрактор, інтерлейкін-8 (IL-8) та інтерлейкін-6 (IL-6).

Відкритий у 2012 р. іризин $є$ пусковим фрактором трансорормації білої жирової тканини в буру, міостатин має інгібуючий вплив на інсуліноподібний фактор росту. Декорин був описаний і віднесений до міокінів нещодавно, його регуляторна функція і вплив на скелетні м'язи наразі залишаються недостатньо вивченими. Остеонектин (SPARC, BM-40) - колагенозв'язуючий матрицелюлярний білок, що регулює внутрішньоклітинні динамічні процеси та в значних кількостях міститься в кістковій тканині. IL-15 експресується в скелетних м'язах, ідентифрікований як анаболічний фрактор та залучений у ліпідний обмін. Також нещодавно було визнано роль мозкового нейротрофічного фрактора в регуляції виживання, росту і життєдіяльності нейронів. IL-8, крім своєї основної ффункції - хемоатрактанта для нейтрофрілів у процесі розвитку імунної відповіді, служить ангіогенним фрактором, його рівень у плазмі зростає при виснажливих ФН [25]. Але першим виявленим і найбільш вивченим міокіном є цитокін рецептора gp130 IL-6. Вказівкою на те, що IL-6 - саме міокін, стало його 100-кратне збільшення в циркулюючій крові під час фрізичних вправ. Поряд з цим було виявлено, що плазмовий рівень IL-6 не тільки прямо корелює 3 інтенсивністю фрізичних вправ, а й обернено пропорційний рівню глюкози в сироватці крові [26].

Існування мережі міокінів як регуляторного апарату, індукованого ФН, протидіє прозапальним адіпокінам жирової тканини. Ця парадигма підводить концептуальну основу, яка пояснює множинні наслідки «сидячого способу життя». Якщо ендокринні і паракринні функції м'язів не стимулюються скороченням, це викликає органічні дисфрункції та підвищений ризик розвитку метаболічних порушень, атеросклерозу, раку i деменції [27]. Міокіни, що виділяються при скороченні м'язів, відіграють головну роль у регуляції взаємодії між скелетними м'язами, печінкою, клітинами підшлункової залози і жировою тканиною.

Інтерлейкін-6. Багатофрункціональний цитокін IL-6 бере участь у регуляції метаболізму, що підтверджує зв'язок між ожирінням і запаленням [28]. Традиційно повідомлялося, що IL-6 відіграє важливу роль у патогенезі IXC і атеросклерозу, нещодавно було висловлено думку, що IL-6 позитивно впливає на організм людини.

IL-6 $€$ найбільш вивченим міокіном. Виявлення продукції IL-6 скелетними м'язами при ФН визначило виникнення інтересу до метаболічної ролі IL-6, давно відомого як медіатора запалення, ендогенного пірогену та індуктора преімунної відповіді. IL-6 у помітних кількостях продукується і вивільняється при ФН, коли посилюється чутливість до інсуліну, водночас IL-6 $€$ протизапальним цитокіном і пов'язаний з розвитком ожиріння та інсулінорезистентності - основними компонентами метаболічного синдрому [29, 30]. Існують серйозні розбіжності в думках вчених 3 приводу потенційного впливу високих системних концентрацій IL-6.

Спочатку вважалося, що IL-6 негативно впливає на гомеостаз глюкози, порушуючи передавання сигналів інсуліну, що призводить до інсулінорезистентності. Пізніше було виявлено, що втрата IL-6 не тільки не може захистити від негативного впливу, але також індукує знижену толерантність до глюкози, що призводить до роз- 
витку ожиріння в зрілому віці. Ці дані показують, що IL-6 важливий для підтримання нормального вуглеводного і ліпідного обміну [31]. Також було висловлено припущення, що циркулюючий IL-6 відіграє важливу роль у розвитку інсулінорезистентності й атеросклерозу завдяки його впливу на метаболізм: зниження чутливості до інсуліну в печінці і поглинання глюкози адипоцитами, а також підвищення рівня інсуліну в плазмі, гіперглікемії та гіперліпідемії (огляд К. Eder et all.) [32]. Інші дослідження доводять, що IL-6 відіграє ліполітичну роль, беручи участь у ліполізі та окисленні жирів. Полеміка загострилася після спостереження за мишами з нокаутом гена IL-6, в яких розвивається ожиріння з гіпертригліцеридемією, зниженою толерантністю до глюкози та іншими особливостями метаболічного синдрому і протилежними результатами цього дослідження, в якому такого явища не спостерігалося, ймовірно, тому що порівняння проводили з різними контрольними штамами мишей [33]. На сьогодні відомо, що клітинна відповідь на IL-6 залежить від метаболічного стану клітини, а також від комбінації інших зовнішніх подразників.

Збільшені системні концентрації IL-6 пов'язані з патофрізіологічними механізмами ЦД 2 та жировою тканиною, яка $є$ основним джерелом цього цитокіну [34, 35]. Вважається, що в цих умовах IL-6 сприяє індукції інсулінорезистентності і погіршенню гомеостазу глюкози.

Фізичні вправи - форма фрізіологічного стресу, взаємозв'язок між стресом і запаленням $€$ гарною моделлю нейроендокринної взаємодії. На сьогодні регулярна фрізична активність розглядається як ефективна немедикаментозна форма втручання при лікуванні ДЛП, покращенні чутливості до інсуліну, діабетичного статусу та імунної відповіді на антигени [36].

Взаємозв'язок фізичних вправ з концентрацією IL-6. Під час фрізичних вправ м'язові скорочення вивільняють і збільшують концентрацію IL-6, таким чином модулюючи гомеостаз глюкози. Попередні дані припускають, що основна функція IL-6 під час вправ - підтримувати обмін глюкози. Інсулін стимулює поглинання глюкози скелетними м'язами, збільшує її вироблення в печінці, щоб підтримувати високий попит на глюкозу м'язовою тканиною [37]. IL-6 секретується Т-клітинами і макрофрагами, є сигнальною молекулою, пов'язаною з метаболізмом. Під час тренування діє як гормоноподібний фрактор, мобілізує енергетичні субстрати, впливаючи на їх доставку в клітини, та реалізує свої протизапальні ефректи через інгібуючу дію на фрактор некрозу пухлин альфа (ФНО $\alpha)$ [23].
IL-6 діє як локально, на самі м'язи, через активацію каскаду АМФ-активованої протеїнкінази (AMPK) / фоссроінозитид-3-кінази (PI3K), так і як гормоноподібна речовина на периферії, наприклад у печінці, жирових клітинах, гіпоталамусі. У першому випадку підвищується захоплення глюкози й окислення ЖК м'язовою тканиною, причому відомо, що IL-6 може накопичуватися в м'язі (тобто вихід у плазму значно менше щодо всього обсягу синтезованого продукту). У другому випадку посилюються процеси ліполізу в жировій тканині, а також глюконеогенезу печінкою. Таким чином, в обох варіантах активності всі есректи IL-6 здійснюються через рецептор сімейства gр130 [24].

Залежно від тренованості людини встановлено зв'язок між рівнем IL-6 у плазмі i внутрішньом'язовою концентрацією IL-6. При гіподинамії відзначається високий вміст IL-6 у плазмі, в той час як постійні тренування знижують цей показник, збільшуючи лише рівень внутрішньом'язової фрракції цитокіну. Тобто хронічна гіподинамія веде до резистентності щодо дії IL-6, що і призводить до підвищення його рівня в плазмі крові. Відомо, що введення IL-6 викликає підвищення чутливості до інсуліну [38]. Інші дослідження показали, що IL-6 збільшує рівень окислення ЖК через активацію каскаду AMPK. У той самий час миші з нокаутом гена IL-6 швидко набирають зайву вагу і страждають на ожиріння різного ступеня [39].

Протизапальну активність IL-6 вивчали на моноцитах. Відомо, що ліпополісахарид (LPS) індукує в моноцитах синтез ФНО $\alpha$, a IL-6 пригнічує його синтезування. Більш того, при введенні антитіл проти IL-6 у мишей $з$ нокаутом гена IL-6 відзначався підвищений рівень ФНО $\alpha$ [23, 40]. Таким чином, IL-6 впливає на метаболізм, призводячи до зростання енергозабезпеченості м'язової тканини (захоплення глюкози, реакції окислення ЖК, підвищення вмісту глюкози в плазмі за рахунок посилення глюконеогенезу печінкою), а також пригнічує синтез одного з найважливіших цитокінів запалення - ФНО $\alpha$.

H. Ellingsgaard et all. виявили, що клітини підшлункової залози є основною мішенню дії IL-6, що сприяє проліфрерації альфа-клітин і пригнічує апоптоз. У спробі пояснити, як підвищені концентрації IL-6 під час ожиріння або фрізичних вправ можуть поліпшити секрецію інсуліну бета-клітинами, вчені припустили, що IL-6 сприяє виробленню і секреції глюкагоноподібного пептиду 1 (GLP-1) L-клітинами кишечнику й альфа-клітинами підшлункової залози, що приводить до поліпшення секреції інсуліну бета-клітинами і толерантності 
до глюкози. Таким чином, IL-6 є гормоном, що опосередковує перехресну взаємодію між чутливими до інсуліну тканинами й острівцями підшлункової залози через GLP-1 [41].

Вплив спрямованості та інтенсивності фізичних навантажень на рівні IL-6. Щоб з'ясувати, чи відіграють підвищені системні рівні IL-6 фрізіологічну роль у регулюванні рівнів GLP-1 у плазмі, Н. Ellingsgaard et all. як модель використовували вправи аеробної спрямованості (біг на біговій доріжці). Системна концентрація IL-6 збільшилася до $100 \pm 20$ пг/мл у відповідь на ФН. Разом з підвищеними концентраціями IL-6 виявили 2,5-кратне збільшення циркулюючого активного GLP-1 у відповідь на 90-хвилинне тренування [41]. В іншій серії експериментів H. Ellingsgaard et all. підтвердили, що системне підвищення рівня IL-6, викликане ФН, збільшує плазмові концентрації GLP-1. Оскільки системно підвищені концентрації IL-6 під час фрізичних вправ стимулювали секрецію GLP-1, дослідники припустили, що різко підвищений рівень IL-6 може поліпшити пероральну толерантність до глюкози за рахунок інкретинової дії GLP-1. Щоб дослідити цю гіпотезу, мишам вводили одноразову ін'єкцію 400 нг IL-6 за 30 хв до введення глюкози з подальшим пероральним введенням. IL-6 поліпшував пероральну толерантність до глюкози.

Експерименти доза-реакція з 4, 40 і 400 нг IL-6 привели до підвищення циркулюючих концентрацій IL-6 у діапазоні від 10 до 550 пг/мл, схожі з концентраціями, які спостерігаються під час аеробного тренування. Всі дози IL-6 покращували толерантність до глюкози, а 40 і 400 нг IL-6 збільшували секрецію інсуліну дозозалежним i глюкозозалежним чином, поряд зі збільшенням плазмових концентрацій GLP-1 [41]. Таким чином, фрізичні вправи аеробної спрямованості супроводжуються збільшенням концентрації GLP-1 у плазмі [42]. Це збільшення опосередковується IL-6, що вивільняється зі скелетних м'язів. Підвищений рівень GLP-1 у відповідь на ФН може бути фрізіологічно значимим завдяки його впливу на перистальтику кишечнику і відчуття насичення, тоді як GLP-1 може покращувати фрункцію бета-клітин після ФН [43]. Слід зазначити, що потенційна дія GLP-1 на секрецію інсуліну залежить від рівня глюкози. Було виявлено, що GLP-1 визначає майбутню секреторну реакцію інсуліну, тобто базальні рівні GLP-1 допомагають підготувати бета-клітини до подальшого прийому їжі, що приводить до потенційної секреції інсуліну, яка стимульована глюкозою [44]. Отже, індукований IL-6 GLP-1, що вивільняється під час тренування, сприятиме секреції інсуліну під час їжі після ФН.

В іншому дослідженні взяли участь 100 саудівських жінок з ожирінням у постменопаузальному періоді, їх вік становив від 50 до 58 років, a IMT - від 30 до 35 кг/м². Дане дослідження було розроблене для порівняння впливу аеробних вправ і вправ з опором на сироваткові рівні запальних цитокінів. Усі учасники були розділені на дві групи: перша (група А) використовувала аеробні вправи на біговій доріжці, а друга (група В) - силові вправи з опором. Учасницям вимірювали рівень TNF- $\alpha$, IL-2, IL-4, IL-6 і C-реактивного білка (CRP) до і через 3 міс. у кінці дослідження.

Група А брала участь в аеробних вправах на біговій доріжці. Програма тренувань включала 5 хв для розминки у вигляді амплітудних рухів і вправ на розтяжку, 30 хв аеробних вправ (60-70\% максимальної частоти пульсу) і 5 хв відновлення (біг на біговій доріжці з низькою швидкістю і без нахилу). В учасників було три тренування на тиждень протягом 3 міс. Група В брала участь у вправах з обтяженнями на тренажерах, кратністю три тренування на тиждень протягом 3 міс.

За результатами дослідження, середні сироваткові значення TNF- $\alpha$, IL-2, IL-4, IL-6 і CRP були значно знижені в обох групах. Крім того, в кінці дослідження була помітна значна різниця між обома групами зі значним акцентом на группу $A$, яка використовувала вправи аеробної спрямованості [45]. Тобто у групі В показники прозапальних цитокінів мали меншу тенденцію до зниження. Це означає, що у жінок 3 ожирінням у постменопаузальному періоді аеробні вправи виявилися досить ефективними порівняно із силовими навантаженнями для регулювання рівня запальних цитокінів.

У наступному дослідженні 23 нетреновані жінки (51,86 \pm 6,58 року, IMT 30,8 \pm 4,3 кг/


без змін у дієті. Беручи до уваги ризик можливих серцево-судинних ускладнень у людей середнього та похилого віку, ризик зводився до мінімуму через фрормування тренувального графріка з урахуванням легкої або помірної інтенсивності ФН, використовуючи поступове збільшення обсягу фрізичних вправ [17]. Тривалість та інтенсивність навантажень варіювалися від 30 до 60 хв і від 50 до $65 \%$ ЧСС протягом усього періоду тренувального графріка.

У сироватці оцінювали рівні IL-1 $\beta$, IL-6, IL-10, TNF- $\alpha$, інтерферон-гамма (IFN- $\gamma$ ). На початковому рівні і через 12 тиж. аеробних тренувань 
учасники пройшли серію антропометричних вимірів (кардіореспіраторний фрітнес-тест, вимірювання ЧСС у спокої), щоб оцінити антропометричні та фрункціональні профрілі. Сироватку і плазму використовували для оцінювання біохімічного статусу, окисного стресу і запального статусу. Щоб звести до мінімуму можливе відхилення в харчуванні, учасникам було рекомендовано підтримувати звичайне споживання їжі під час дослідження із заповненням триденного звіту про дієту [46]. Це дослідження показало, що 12-тижневі аеробні тренування середньої та низької інтенсивності знижували рівні IL-1 $\beta$, IL-6, TNF- $\alpha$ і INF- $\gamma$ в сироватці, у той час як рівень IL10 підвищувався. Було запропоновано деякі механізми, що пояснюють, як ФН можуть зменшити хронічне запалення при МС. Працюючі скелетні м'язи є потенційним джерелом цитокінів. IL-6, що продукується міоцитами за допомогою активації АМРК при контрольованій інтенсивності аеробних вправ, проявляє протизапальну дію, на відміну від IL-6, що секретується жировою тканиною [20, 46].

Узагальнюючи, можна зазначити, що аеробні тренування середньої та низької інтенсивності дозволяють позитивно впливати на окислювальний стрес і запальну модуляцію у жінок з МС. Це дослідження може служити основою подальшої рандомізації досліджень, спрямованих на оцінювання впливу різних програм тренувань на запальні цитокіни. Більш того, ефекти тих самих біомаркерів після періоду відсторонення від тренувань вимагають уточнення.

Експериментальне дослідження В. K. Pedersen підтвердило, що ФН характеризуються протизапальною дією. У модель «запалення низького ступеня» було введено низьку дозу ендотоксину E. coli, що викликала помірне збільшення концентрації TNF- $\alpha$ в плазмі і вводилася здоровим суб'єктам, які були рандомізовані на контрольну та основну групи. Ендотоксин викликав двоабо триразове збільшення циркулюючих рівнів TNF- $\alpha$. Однак коли учасники виконували аеробні вправи середньої інтенсивності (3 год їзди на ергометрі), підвищення TNF- $\alpha$ було повністю знівельовано. Ефект від вправ можна імітувати інфузією IL-6, що пригнічує індуковане ендотоксинами вироблення TNF- $\alpha$. Це дослідження позитивно корелює з дослідженнями, які показують, що IL-6 пригнічує індуковане LPS вироблення TNF- $\alpha$ в культивованих моноцитах людини [20].

Крім того, дослідження in vivo підтверджують позитивну роль IL-6 у запобіганні розвитку серцево-судинних ускладнень, оскільки було показано, що підвищення концентрації IL-6 у си- роватці сприяє фрормуванню механізмів розвитку атеросклерозу як на моделях тварин, так і за участю людей [47].

Представлені дані показують, що аеробні тренування контрольованої середньої та низької інтенсивності мають протизапальний ефект, що частково опосередкований IL-6, а також протективний ефект щодо запобігання виникненню серцево-судинних ускладнень в осіб з ожирінням та МС.

Висновки. Детальний аналіз наукової літератури та представлених даних рандомізованих досліджень виявив позитивну кореляцію взаємозв'язку концентрації IL-6 з розвитком та прогресуванням інсулінорезистентності, артеріальної гіпертензії, дисліпідемії та ожирінням, об'єднуючою основою яких $€$ розвиток метаболічного синдрому. Також слід відзначити, що на тлі метаболічного синдрому зростає ризик розвитку серцево-судинних, легеневих, ниркових та онкологічних захворювань.

Дослідження останніх років показали, що скелетні м'язи, так само як кардіоміоцити і жирова тканина, $€$ ендокринним органом та виробляють біорегулятори. Міокіни, що виділяються при скороченні м'язів, відіграють головну роль у регуляції взаємодії між скелетними м'язами, печінкою, клітинами підшлункової залози і жировою тканиною. Вивільнення IL-6 при роботі скелетних м'язів дає можливість стверджувати, що фрізичні навантаження аеробної спрямованості безпосередньо впливають на метаболічні процеси, беручи участь у ліполізі, окисленні жирів та модулюючи гомеостаз глюкози.

У багатьох представлених дослідженнях за участю жінок з ожирінням використання низькота середньоінтенсивних вправ аеробної спрямованості виявилося одним з ефективних методів для регулювання рівня запальних цитокінів порівняно із силовими тренуваннями. За результатами досліджень, знижувалися середні значення TNF- $\alpha$, IL-2, IL-4 і CRP, а також відзначалося, що IL-6, що продукується міоцитами при достатній інтенсивності аеробних вправ, проявляє протизапальну дію, на відміну від IL-6, що секретується жировою тканиною.

Результати аналізу літературних джерел підтверджують, що використання вправ аеробної спрямованості здійснює модифікуючий вплив на процеси гормональної регуляції ліпідного та вуглеводного обміну, знижує секрецію прозапальних цитокінів, модулює гомеостаз глюкози через секрецію IL-6 скелетними м'язами, що передбачає перспективність наукових досліджень щодо їх застосування як одного з компонентів прото- 
колу у лікуванні та профрілактиці метаболічного синдрому.

Перспективи подальших досліджень. У подальших дослідженнях плануються детальне

\section{Література}

1. Myloslavskyy DK, Koval SM, Snegurskaya IA, Bozhko VV. Modern views on therapeutic and prophylactic nutrition and most efficient European diets during metabolic syndrome and its components. Mizhnarodnyy endokrynologichnyy zhurnal. 2019;4(76):118-124.

2. Tanashyan MM, Orlov SV, Domashenko MA, Ionova VG. Metabolic syndrome and ischemic stroke. Annaly klinicheskoy i eksperimentalnoy nevrologii. 2007;(3).

3. Geneva SW. Global status report on non-communicable diseases. $2015 ; 282$.

4. Moore JX, Chaudhary N, Akinyemiju T. Metabolic syndrome prevalence by race/ethnicity and sex in the United States, National Health and Nutrition Examination Survey, 1988-2012. Prev Chronic Dis. 2017;14:24. doi: 10.5888/ pcd14.160287.

5. Tyrtova LV, Parshina NV, Skobeleva KV. Geneticheskie i epigeneticheskie aspekty ozhireniya i metabolicheskogo sindroma, vozmozhnosti profilaktiki v detskom vozraste. Pediatr. 2013;4(2):3-11.

6. Chazova IE, Mychka VB. Metabolic syndrome and hypertension. Consilium medicum. 2002;(11):587-90. [in Russian]

7. Petrishcheva NN, editor. 9-ya Mezhdunarodnaya konferentsiya «Disfunktsiya endoteliya» Eksperimentalnye i klinicheskie issledovaniya. In: Disfunktsiya endoteliya Prichiny, mekhanizmy, farmakologicheskaya korrektsiya. Izd. S. Peterb. gos. med. universitet im. akad. I. P. Pavlova; 2003.

8. Alberti KG, Zimmet PZ. Definition, diagnosis and classification of diabetes mellitus and its complications. Part 1: diagnosis and classification of diabetes mellitus provisional report of a WHO consultation. Diabet Med. 1998;15(7):539-53. doi: 10.1002/(SICI)1096-9136(199807)15:7<539.

9. Botsyurko VI, Didushko OM, Kostitska IA. Chi potriben diagnoz metabolichniy sindrom. Mizhnarodniy endokrinologichniy zhurnal. 2018:14(6):590-2.

10. Expert Panel on Detection, Evaluation, and Treatment of High Blood Cholesterol in Adults. Executive summary of the third report of the national cholesterol education program (NCEP) expert panel on detection, evaluation, and treatment of high blood cholesterol in adults (adult treatment panel III). JAMA. 2001;285(19):2486-97. doi: 10.1001/jama.285.19.2486.

11. Efremenko YR, Kontorshchikova KN, Koroleva EF. Diagnosis of metabolic syndrome as prevention of cardiovascular diseases. Meditsinskiy almanakh. 2013;2(26):175-7.

12. Oleynik OA, Samoylova YuG, Vorozhtsova IN, Denisenko TN, Bashnyak MV. Kliniko-metabolicheskie i molekulyarno-geneticheskie mekhanizmy formirovaniya kardiovaskulyarnykh oslozhneniy pri ozhirenii. Sibirskiy zhurnal klinicheskoy i eksperimentalnoy meditsiny. 2011;26(4-2):1621. [in Russian]

13. Sosnova EA. Metabolic syndrome. Arkhiv akusherstva i ginekologii im. V. F. Snegireva. 2016;3(4):172-80.

14. Komissarenko IA. Polimorbidnost i metabolicheskiy sindrom u pozhilykh. Klinicheskaya gerontologiya. 2009;(15):29-38.

15. Lifshits GI, Kokh NV, Kireeva VV. Nekotorye molekulyarnogeneticheskie mekhanizmy formirovaniya ozhireniya i metabolicheskogo sindroma. Farmakogenetika i farmakogenomika. 2017;(1):5-9. [in Russian]

16. Paley CA, Johnson MI. Abdominal obesity and metabolic syndrome: exercise as medicine? BMC Sports Sci Med Rehabil. 2018;10:7. doi: 10.1186/ s13102-018-0097-1.

17. Nocon M, Hiemann T, Müller-Riemenschneider F, Thalau F, Roll S, Willich SN. Association of physical activity with all-cause and cardiovascular mortality: a systematic review and meta-analysis. Eur J Cardiovasc Prev Rehabil. 2008;15(3):239-46. doi: 10.1097/HJR.0b013e3282f55e09.

18. Motamed S, Mazidi M, Safarian M, Ghayour-Mobarhan M, Moohebati $M$, Ebrahimi $M$, et al. Macronutrient intake and physical activity levels in вивчення та оцінювання динаміки біохімічних показників діагностики метаболічного синдрому під впливом фрізичних навантажень аеробної спрямованості.

individuals with and without metabolic syndrome: An observational study in an urban population. ARYA Atheroscler. 2019;15(3):136-45. doi: 10.22122/arya. v15i3.1303.

19. Myers J, Kokkinos P, Nyelin E. Physical activity, cardiorespiratory fitness, and the metabolic syndrome. Nutrients. 2019;11(7):1652. doi: 10.3390/ nu11071652.

20. Pedersen BK. Anti-inflammatory effects of exercise: role in diabetes and cardiovascular disease. Eur J Clin Invest. 2017;47(8):600-11. doi: 10.1111/ eci. 12781.

21. Xiao J, Shen C, Chu MJ, Gao YX, Xu GF, Huang JP et al. Physical activity and sedentary behavior associated with components of metabolic syndrome among people in rural China. PLoS One. 2016;11(1):0147062. doi: 10.1371/journal.pone.0147062.

22. Abdullozoda SM. Nekotorye aspekty epidemiologii i etiopatogeneza metabolicheskogo sindroma. Vestnik Avitsenny. 2020;22(4):580-94. [in Russian]

23. Vasina AYu, Didur MD, lygi AA. Myshechnaya tkan kak endokrinnyy regulyator i problema gipodinamii. Vestnik Sankt-Peterburgskogo universiteta. Meditsina. 2014;(2):5-11. [in Russian]

24. Pedersen BK, Febbraio MA. Muscle as an endocrine organ: focus on muscle-derived interleukin-6. Physiol Rev. 2008;88(4):1379-406. doi: 10.1152/ physrev.90100.2007.

25. Tsoriev TT, Belaya ZhE, Rozhinskaya LYa. Rol miokinov $v$ mezhtkanevom vzaimodeystvii i regulyatsii obmena veshchestv: obzor literatury. Osteoporoz i osteopatii. 2016;(1):28-34.

26. Nehlsen-Cannarella SL, Fagoaga OR, Nieman DC, Henson DA Butterworth DE, Schmitt RL, et al. Carbohydrate and the cytokine response to $2.5 \mathrm{~h}$ of running. J Appl Physiol. 1997;82(5):1662-7.

27. Pedersen BK. The diseasome of physical inactivity and the role of myokines in muscle fat cross talk: Diseasome of physical inactivity. J Physiol. 2009;587(23):5559-68. doi: 10.1113/jphysiol.2009.179515.

28. Recasens M, Ricart W, Fernández-Real JM. Obesity and inflammation. Rev Med Univ Navarra. 2004;48(2):49-54.

29. Ostrowski K, Rohde T, Asp S, Schjerling P, Pedersen BK. Pro- and anti-inflammatory cytokine balance in strenuous exercise in humans. J Physiol. 1999;515(1):287-91. doi: 10.1111/j.1469-7793.1999.287ad.x.

30. Croisier JL, Camus G, Venneman I, Deby-Dupont G, Juchmès-Ferir A, Lamy $M$, et al. Effects of training on exercise-induced muscle damage and interleukin 6 production. Muscle Nerve. 1999;22(2):208-12. doi: 10.1002/ (sici)1097-4598(199902)22:2<208::aid-mus8>3.0.co;2-b.

31. Senn JJ, Klover PJ, Nowak IA, Mooney RA. Interleukin-6 induces cellular insulin resistance in hepatocytes. Diabetes. 2002;51(12):3391-9. doi: 10.2337/diabetes.51.12.3391.

32. Eder K, Baffy N, Falus A, Fulop AK. The major inflammatory mediator interleukin-6 and obesity. Inflamm Res. 2009;58(11):727-36. doi: 10.1007/ s00011-009-0060-4

33. Martín-Cordero L, García JJ, Hinchado MD, Ortega E. The interleukin-6 and noradrenaline mediated inflammation-stress feedback mechanism is dysregulated in metabolic syndrome: effect of exercise. Cardiovasc Diabetol. 2011;10(1):42. doi: 10.1186 / 1475-2840-10-42.

34. Spranger J, Kroke A, Möhlig M, Hoffmann K, Bergmann MM, Ristow $\mathrm{M}$, et al. Inflammatory cytokines and the risk to develop type 2 diabetes: results of the prospective population-based European Prospective Investigation into Cancer and Nutrition (EPIC)-Potsdam Study. Diabetes. 2003;52(3):812-7. doi: $10.2337 /$ diabetes.52.3.812.

35. Mohamed-Ali V, Goodrick S, Rawesh A, Katz DR, Miles JM, Yudkin JS et al. Subcutaneous adipose tissue releases interleukin-6, but not tumor necrosis factor-alpha, in vivo. J Clin Endocrinol Metab. 1997;82(12):4196-200. doi: $10.1210 /$ jcem.82.12.4450. 
36. Martín-Cordero L, García JJ, Hinchado MD, Bote E, Manso R, Ortega E. Habitual physical exercise improves macrophage IL- 6 and TNF-a deregulated release in the obese zucker rat model of the metabolic syndrome. Neuroimmunomodulation. 2011;18(2):123-30. doi: 10.1159/000322053.

37. Kurauti MA, Costa-Júnior JM, Ferreira SM, Santos GJ, Sponton CHG, Carneiro EM, et al. Interleukin-6 increases the expression and activity of insulindegrading enzyme. Sci Rep. 2017;7(1):467-50. doi: 10.1038/srep46750.

38. LA, MH, LB. Differential induction of interleukin-6 production in monocytes, endothelial cells and smooth muscle cells // Eur. Cytokine Netw. 1991;2(2).

39. S. R, J E. Adipo-Myokines: Two Sides of the Same Coin - Mediators of Infl ammation and Mediators of Exercise. Mediators of Infl ammation. 2013: 1-16. doi: $10.1155 / 2013 / 320724$.

40. Nieman DC, Davis JM, Brown VA et al. Influence of carbohydrate ingestion on immune changes aft er $2 \mathrm{~h}$ of intensive resistance training. $\mathrm{J}$ Appl Physiol. 2004;96:1292-98. doi: 10.1152/japplphysiol.01064.2003.

41. Ellingsgaard $H$, Hauselmann I, Schuler B, Habib AM, Baggio LL, Meier DT et al. Interleukin-6 enhances insulin secretion by increasing glucagon-like peptide-1 secretion from $L$ cells and alpha cells. Nat Med. 2011;17(11):1481-9. doi: 10.1038/nm.2513.

42. Ueda S-Y, Yoshikawa T, Katsura Y, Usui T, Nakao H, Fujimoto S. Changes in gut hormone levels and negative energy balance during aerobic

Sdrozdovska@gmail.com

olggurenko@gmail.com exercise in obese young males. J Endocrinol. 2009;201(1):151-9. doi: 10.1677/ JOE-08-0500

43. Dela F, von Linstow ME, Mikines KJ, Galbo H. Physical training may enhance beta-cell function in type 2 diabetes. Am J Physiol Endocrinol Metab. 2004;287(5):E1024-31. doi: 10.1152/ajpendo.00056.2004.

44. Hinke SA, Hellemans K, Schuit FC. Plasticity of the beta cell insulin secretory competence: preparing the pancreatic beta cell for the next meal: Plasticity of $\beta$ cell insulin secretory competence. J Physiol. 2004;558(Pt 2):36980. doi: 10.1113/jphysiol.2004.064881.

45. Abd El-Kader SM, Al-Jiffri OH. Impact of aerobic versus resisted exercise training on systemic inflammation biomarkers and quality of Life among obese post-menopausal women. Afr Health Sci. 2019;19(4):2881-91. doi: 10.4314/ahs.v19i4.10

46. Farinha JB, Steckling FM, Stefanello ST, Cardoso MS, Nunes LS, Barcelos RP et al. Response of oxidative stress and inflammatory biomarkers to a 12-week aerobic exercise training in women with metabolic syndrome. Sports Med Open. 2015;1(1):19. doi: 10.1186/s40798-015-0011-2.

47. Van Lenten BJ, Wagner AC, Navab M, Fogelman AM. Oxidized phospholipids induce changes in hepatic paraoxonase and ApoJ but not monocyte chemoattractant protein-1 via interleukin-6. J Biol Chem. 2001;276(3):1923-9. doi: 10.1074/jbc.M004074200. 